\title{
Seismicity of Czorsztyn Lake Region: A Case of Reservoir Triggered Seismic Process?
}

\author{
Wojciech BIAŁOŃ, Ewa ZARZYCKA, and Stanisław LASOCKI \\ Institute of Geophysics, Polish Academy of Sciences, Warszawa, Poland \\ e-mails: w.bialon@igf.edu.pl (corresponding author), ezarzycka@igf.edu.pl, \\ lasocki@igf.edu.pl
}

\begin{abstract}
Czorsztyn Lake is an artificial water reservoir backed up by the hydropower plant Niedzica earth dam on Dunajec River in south Poland. Its filling began in 1995 and ended in 1997. The reservoir of 234.5 million $\mathrm{m}^{3}$ capacity is shallow, between 20 to $50 \mathrm{~m}$ of water column, on average. Until 2011 the seismic activity in this region was sparse, some 1 event trimonthly. However, in November 2011 more than 60 events occurred. Such bursts of activity, separated by low activity periods, continue to appear. Since August 2013 the area is monitored by a local seismic network. The setup allows to accurately locate the epicenters and to determine source mechanisms for stronger events. The events are clustered and aligned along NE-SW direction and their mechanisms are very similar, indicating N-S strike slip faulting. This and the irregular pattern of activity suggest that this seismicity is triggered by the reservoir impoundment.
\end{abstract}

Key words: triggered and induced seismicity, Pieniny Klippen Belt.

\section{INTRODUCTION}

The system of two artificial lakes, Czorsztyn-Niedzica and Sromowce Wyżne, locates in the edge of Nowy Targ Valley in close neighborhood of

Ownership: Institute of Geophysics, Polish Academy of Sciences;

(C) 2015 Białoń et al. This is an open access article distributed under the Creative Commons Attribution-NonCommercial-NoDerivs license,

http://creativecommons.org/licenses/by-nc-nd/3.0/. 
the Pieniny National Park and the Middle Ages castle in Niedzica. The history of building an artificial lake in the upper course of Dunajec River started at the beginning of 20th century. According to Bajorek and Zielińska (2010), first works concerning a use of energy of Carpathian rivers were due to engineers K. Pomianowski and T. Becker in 1904; another work was due to Prof. G. Narutowicz in 1911. The plan of building dams in Rożnów and Czorsztyn-Niedzica was developed in 1934. Because of economic reasons building of only the dam in Rożnów was undertaken and started in 1935. After the 2nd World War, the idea of building the dam in Czorsztyn-Niedzica was resumed in 1967. In 1971, preparatory works began, new roads were made, and environmental works started. The main construction works started in 1975. Impoundment of the reservoir began in 1995 and the hydropower plant Niedzica was made operational in 1997.

The dam in Niedzica on Dunajec River (Fig. 1) is the biggest earth dam in Poland. The dam length is $404 \mathrm{~m}$, the width at the base is $300 \mathrm{~m}$ and the maximum height from the control tunnel foundation is $56 \mathrm{~m}$. The maximum capacity of Czorsztyn reservoir is 234.5 million $\mathrm{m}^{3}$ with the average depth from about $20 \mathrm{~m}$ to about $50 \mathrm{~m}$ at the front of the dam. Sromowce Wyżne Lake is an auxiliary reservoir for Czorsztyn Lake (Fig. 2). The maximum capacity of Sromowce Lake is 6.7 million $\mathrm{m}^{3}$, and the maximum height of its embankment is $11 \mathrm{~m}$. Both dams hold electric power generators. In Niedzica dam there are 2 reversible generators with the total power up to $92.75 \mathrm{MW}$. In Sromowce there are 4 small generators with total power of about 2 MW. The detailed technical information can be found on the website: www.zewniedzica.com.pl. Main tasks of the reservoir system are: flood control, water supply and irrigation of surrounding areas, and electricity production (Bajorek and Zielińska 2010).

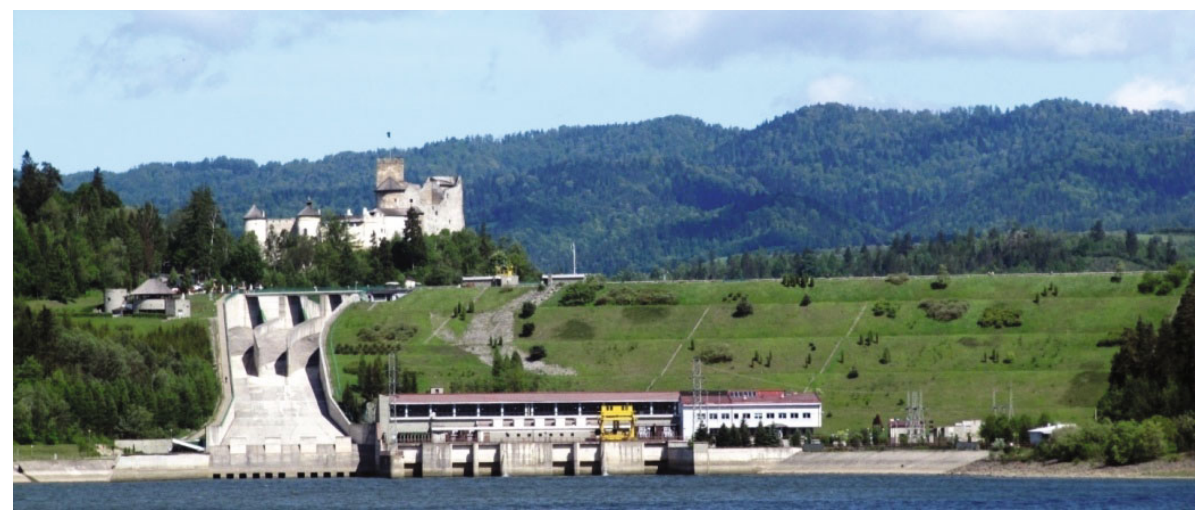

Fig. 1. The dam in Niedzica on Dunajec River. View from the weir of Sromowce Lake. 


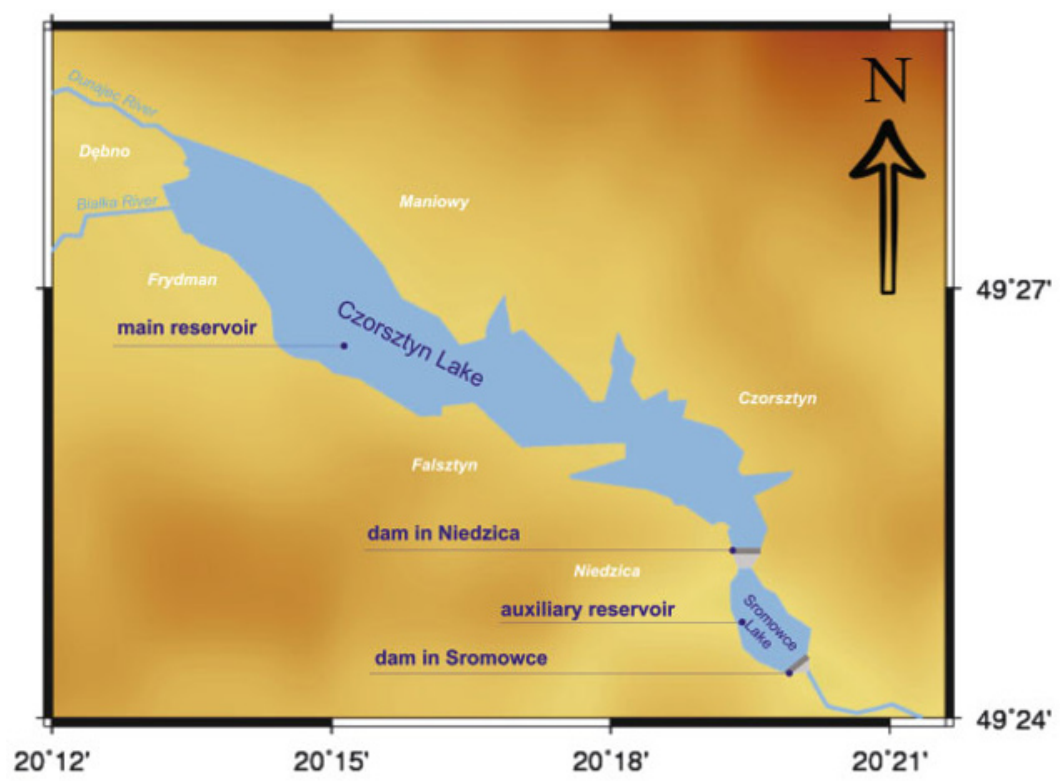

Fig. 2. Plan view of Czorsztyn Lake and Sromowce Lake.

Figure 3 shows a geological-tectonic map of the Czorsztyn Lake area with major tectonic borders and Miocene faults (Birkenmajer 2003). Czorsztyn Lake is situated in a border zone of two major Carpathian tectonic units: Inner and Outer Carpathians. The border zone is formed by Magura unit from the north and Pieniny Klippen Belt (PKB) from the south. Magura unit is a part of the Outer Carpathians. PKB separates the Inner Carpathians from the Outer Carpathians. According to Birkenmajer (2003), PKB extends for over $600 \mathrm{~km}$ as a north curved arc from the Tertiary Vienna depression up to Romania. PKB width varies from several kilometers, sometimes decreasing to just a few hundred meters. PKB has an extremely complicated geological-tectonic structure; it is cut by a series of young faults mostly of $\mathrm{N}-\mathrm{S}$ strikes. PKB is mostly built of carbonate rocks (limestone and marlstone), shale, and claystone. Its narrow width and the significant length suggest correlation with a dislocation or a system of dislocations extending along the tectonic boundary of Western Carpathians.

The Niedzica dam locates at the eastern border of Orawa - Nowy Targ Basin. Compared to a negligible seismicity of Poland, the Orawa-Nowy Targ Basin area is known as the most seismically active zone in the Polish Carpathians, despite the fact that earthquakes in this region occur sporadically. The first information about earthquakes in this region dates back to 1717 . Other earthquakes were observed in 1840, 1901, 1935, and 1966. Stronger 


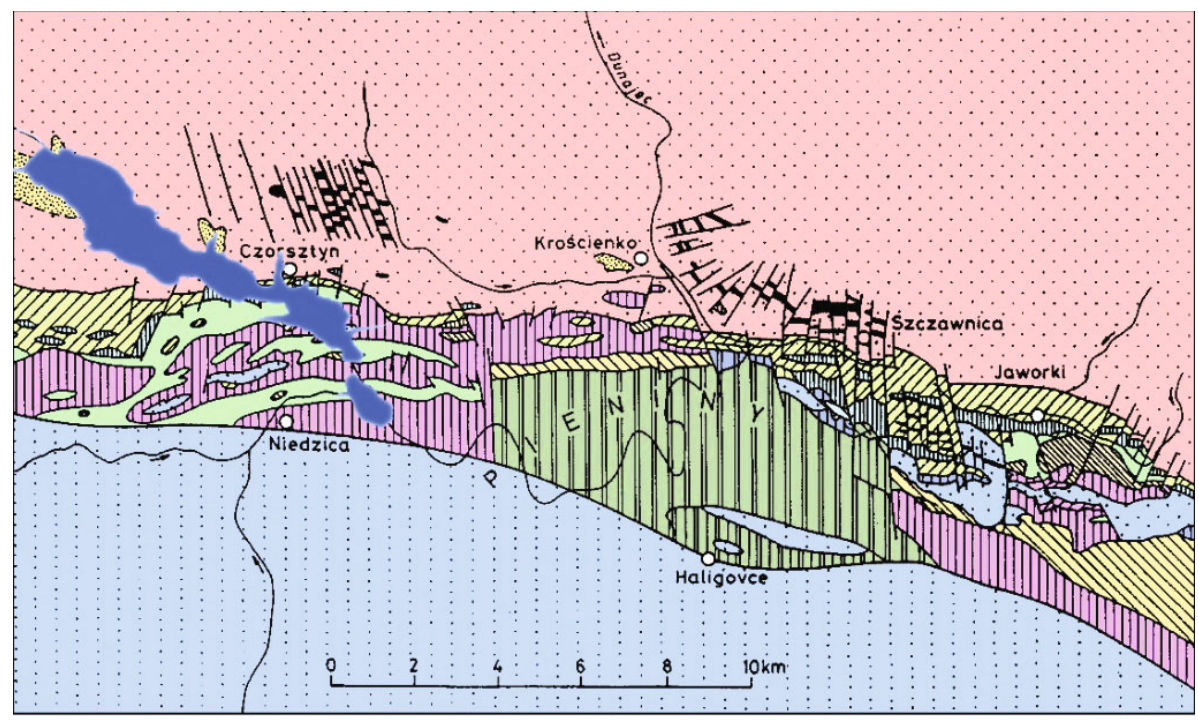

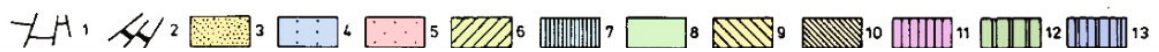

Fig. 3. Geological-tectonic map of the Czorsztyn Lake area (Birkenmajer 2003, map modified): 1 - Miocene fault system; 2 - Sarmatian andesite intrusions; 3 - freshwater Neogene deposits; 4 - Inner-Carpathian Paleogene; 5 - Magura Paleogene; 6, 7 - Laramian Grajcarek Unit; 8-13 - tectonic units of Pieniny Klippen Belt: 8 Czorsztyn, 9 - Czertezik, 10 - Niedzica, 11 - Branisko, 12 - Pieniny, and 13 Haligovce.

seismic events occurred in the area of Krynica in 1992-1993 and in Podhale region in 1995 and in 30 November 2004 (Guterch et al. 2005). From 1998 to 2010 only 54 earthquakes were recorded in a direct area of Czorsztyn Lake, which makes, on average, about one event in three months. Unexpectedly, a significant increase of seismic activity was noticed in 2011. More than 60 seismic events were recorded close to Czorsztyn Lake in November 2011. Most of them were weak. The strongest earthquake, which occurred on 5 November 2011, had magnitude $M_{w} 2.6$. After November 2011, the activity returned to its previous low level. However, since January 2013 a gradual increase of activity was noted. In March 2013, 177 earthquakes occurred. The strongest event had magnitude $M_{w} 3.5$.

\section{SENTINELS}

The first instrumental measurements of the seismicity in Orawa-Nowy Targ Basin began in the 1960-ies with installing in Niedzica a seismological station of the Institute of Geophysics PAS. In a response to the increasing seismicity in the Czorsztyn Lake vicinity, observed since 2011, the Institute of 
Geophysics PAS in cooperation with Niedzica Hydro Power Plants Company (Zespół Elektrowni Wodnych Niedzica S.A., ZEW Niedzica S.A.) launched local seismic network SENTINELS (SEismic Network for TrIggered and Natural Earthquake Location and Source determination) on 24 August 2013. The current SENTINELS network consists of seven shortperiod seismic stations and one broadband station. The short period stations comprise Lennartz 3D Lite seismometers and NDL recorders, the broadband station has STS-2 Kinemetrics seismometer and MK-6 recorder. NDL and MK6 recorders have been made by Institute of Geophysics PAS. More technical information can be found on the website: www.igf.edu.pl. The SENTINELS stations are emplaced around Czorsztyn Lake in facilities of ZEW Niedzica S.A., Krościenko administration of forestland and Nowy Targ municipality. Present locations of the SENTINELS stations are shown in Fig. 4. Before the SENTINELS network was set, locations of epicenters of

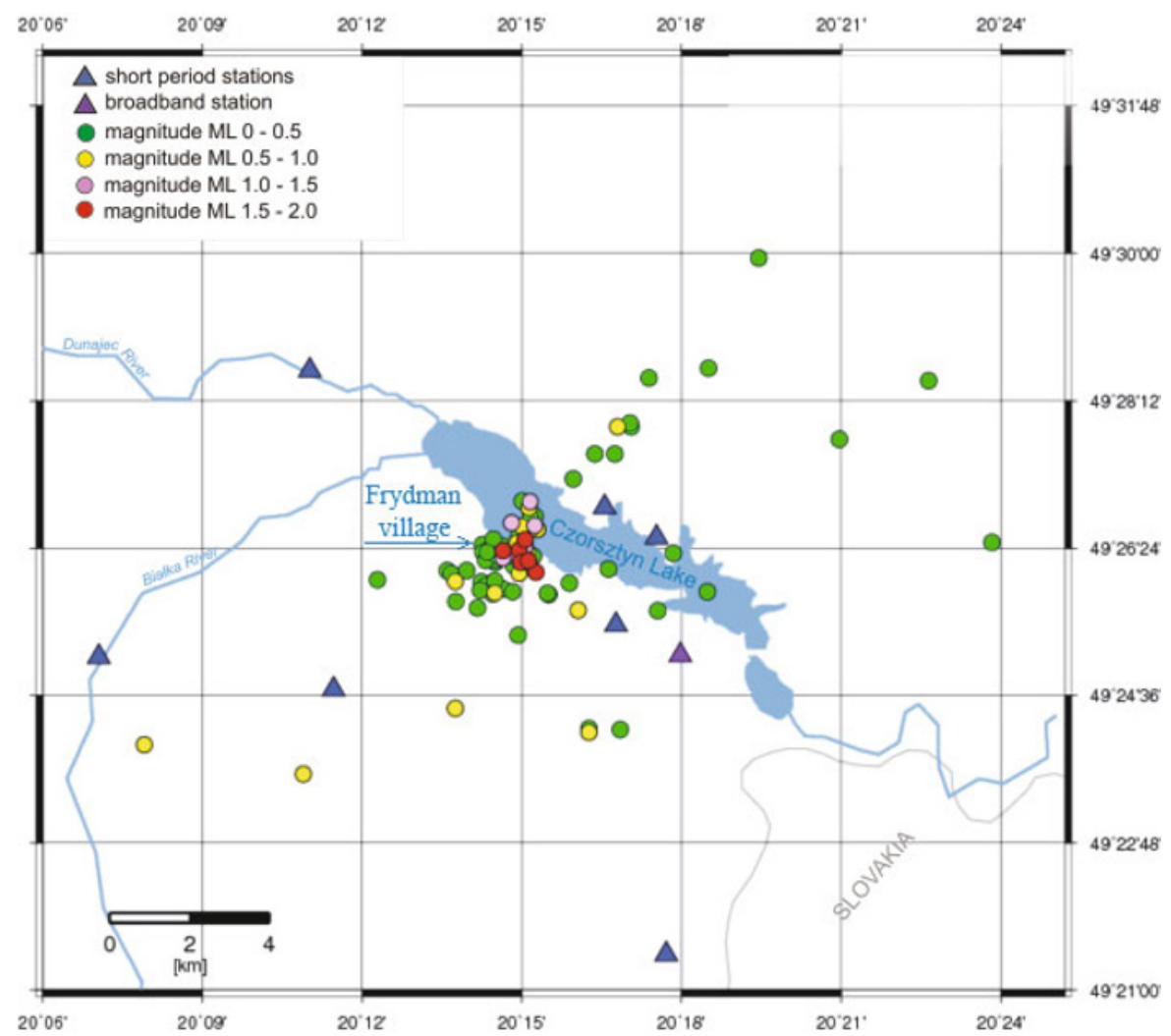

Fig. 4. Locations of earthquake recorded by SENTINELS network in the Czorsztyn Lake region from August 2013 to June 2014. Circles represent epicenters, triangles mark seismic stations. 
only the strongest earthquakes had been determined. For this purpose, waveforms from the broadband station in Niedzica, from local Podhale stations which belong to the Institute of Geophysics PAS, and from far Czech and Slovakian stations were used. Due to an irregular distribution of all these stations as well as significant distances of some of them from the study area, the accuracy of epicenter location was not high. The SENTINELS network enables recording and more precise parameterization of weaker events. Earthquakes from local magnitude $M_{L} 0.1$ are recorded, and the catalog is complete from $M_{L} 0.5$. The SENTINELS network will be modernized in the framework of the project IS-EPOS "Digital Research Space of Induced Seismicity for EPOS Purpose", co-financed from the funds of the European Regional Development Fund (ERDF) as part of the Operational Program Innovative Economy (www.is-epos.eu). The number of seismic stations will be increased to 10 and the data downloading interface will be upgraded. In order to reduce ambient noise, some of the stations will be relocated. Additionally, seismic profiling studies are foreseen in order to develop the first detailed velocity model of the subsurface in PKB region and to get an insight into local geotectonics from the viewpoint of the seismogenesis.

\subsection{Seismicity of Czorsztyn Lake area}

Digital records from broadband Niedzica station are available since May 1998. The numbers of earthquakes daily in the period from May 1998 to June 2014 are shown in Fig. 5. As mentioned in the introduction, until November 2011 earthquakes in the Czorsztyn Lake region were noticed only occasionally. From 1998 until November 2011, 60 seismic events were recorded; the strongest one occurred on 4 January 2005 and had magnitude $M_{w} 2.0$.

The first period of increased seismic activity took place from November to December 2011. 82 seismic events were recorded in this period (63 in November and 19 in December). The strongest earthquake had magnitude $M_{w} 2.9$. The second period of increased seismic activity occurred from July to September 2012. 29 earthquakes were recorded (12 in July, 14 in August, and 3 in September). The strongest event had magnitude $M_{w} 2.4$ and took place in September. The strongest activity was observed in the third period between December 2012 and March 2013. 290 earthquakes were recorded, $13,26,77$, and 174 in the consecutive months, respectively. The strongest earthquake so far in this region occurred on 1 March 2013. Its magnitude was $M_{w} 3.5$. This event was felt by inhabitants of the area.

From the beginning of observations by means of SENTINELS network (24 August 2013) 101 earthquakes were recorded in the vicinity of Czorsztyn Lake. The greatest number of seismic events was noted in September 


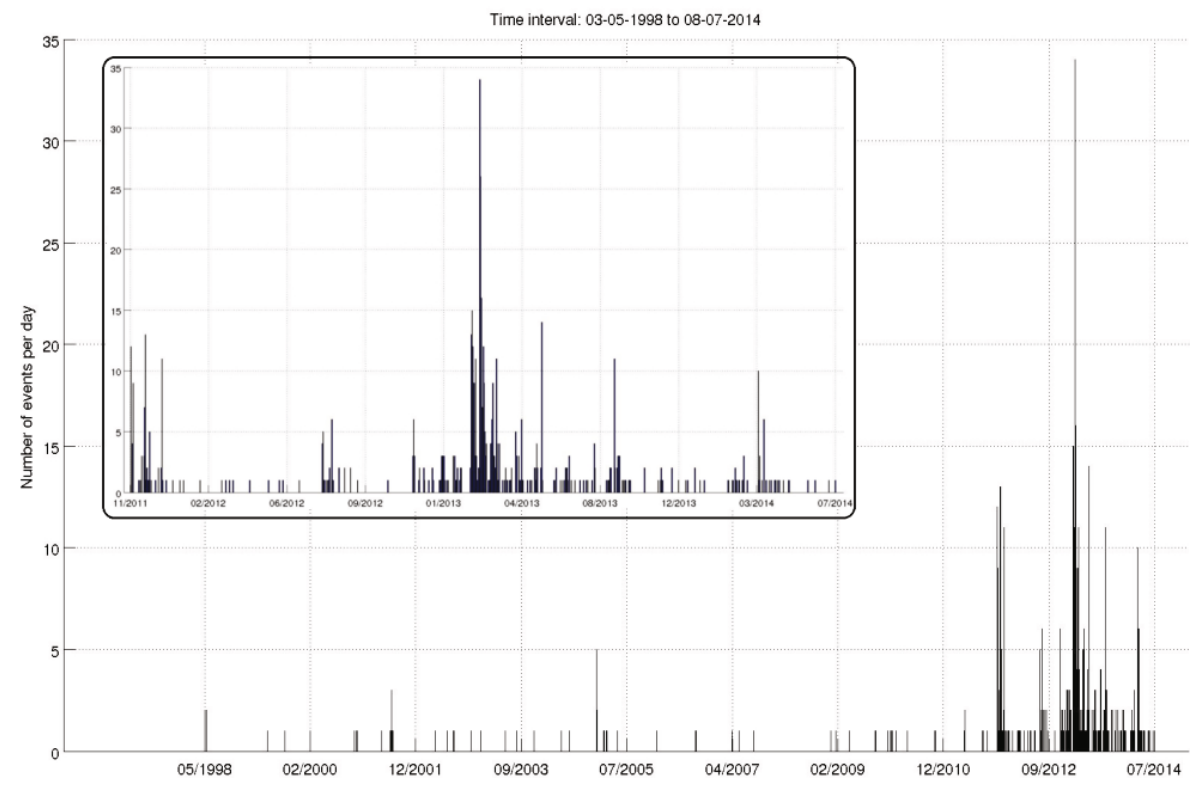

Fig. 5. Numbers of earthquakes daily from May 1998 to June 2014, with zoomed period from November 2011 to June 2014.

2013 (29 events) and in March 2014 ( 24 events). The strongest seismic event recorded by SENTINELS network so far took place on 1 April 2014 and had magnitude $M_{w} 3.1$. Epicenters of earthquakes are grouped at around Frydman village, which locates on the south-west shore of the lake. The epicenters are arranged in a belt extending from the north-east to the south-west (Fig. 4).

The average depth of earthquakes is approximately $6.5 \mathrm{~km}$. The hypocenter of the deepest earthquake was at about $9 \mathrm{~km}$ below the surface and the hypocenter of the shallowest one was at about $2 \mathrm{~km}$ below the surface. For all recorded events, local magnitude $M_{L}$ is determined; for stronger events, also moment magnitude $M_{w}$ is calculated. Magnitude completeness level for SENTINELS observations is 1.4 for moment magnitude $M_{w}$ and 0.5 for local magnitude $M_{L}$.

It was possible to evaluate focal mechanism for 16 strongest events. The calculations were done by means of the program FOCI (Kwiatek 2011), which implements a seismic moment tensor inversion in time domain (Wiejacz 1992). The resultant mechanisms are shown in Fig. 6. All mechanisms are very similar: strike slip faulting with a very small dip slip component. The result suggests a common genesis of these earthquakes. The mechanism of the earthquake located by the south-west edge of the area is different however, the result is uncertain because the event was located nearly outside the network. 


\section{DOUBLE COUPLE}

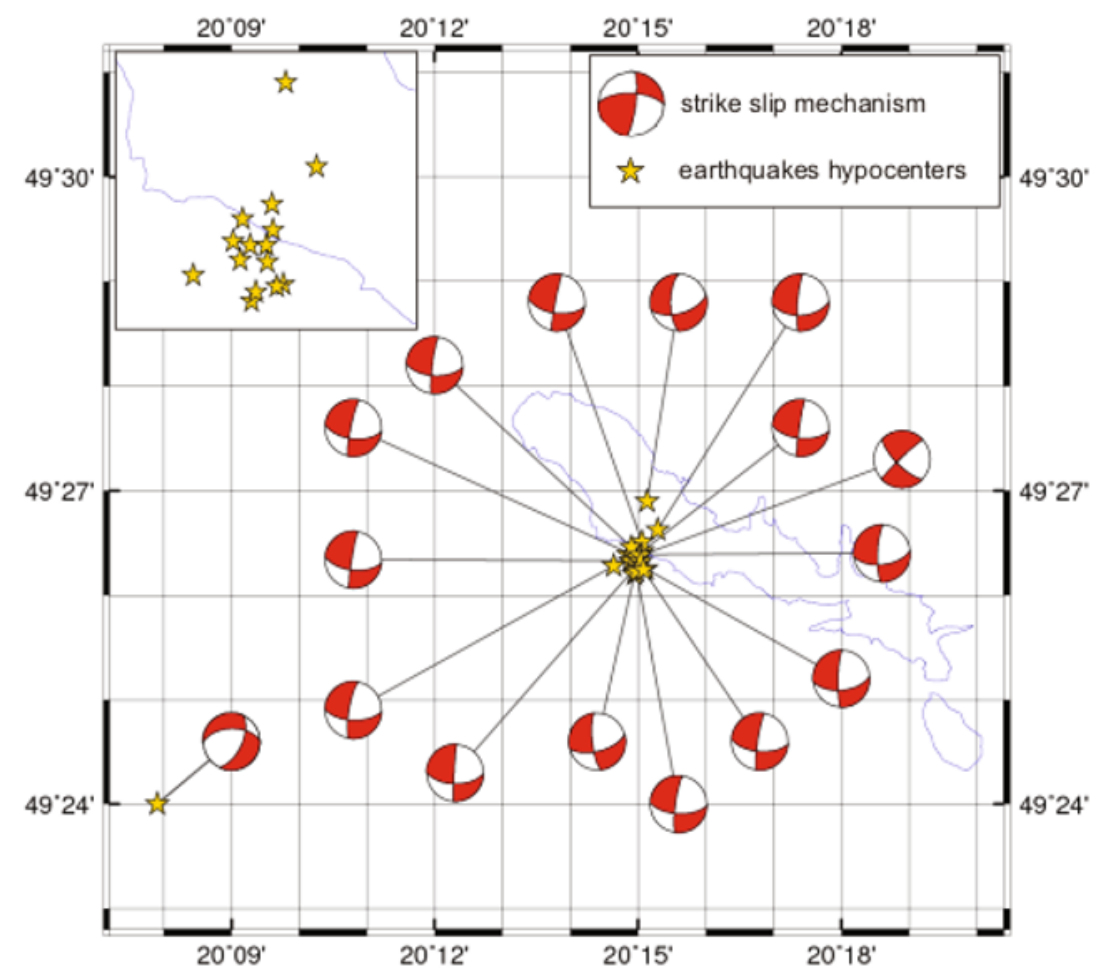

SM] 2014 Jun 12 12:55:21 CYUNOAICAL PROJECTONS Mercator

Fig. 6. Mechanisms of earthquake from Czorsztyn Lake region.

\section{DISCUSSION AND CONCLUSIONS}

The significantly increased seismic activity since 2011 is highly irregular. In some periods, the earthquake productivity is much higher than in the others. Both, the increase of seismic activity and its time irregularity suggest a connection of this seismicity with the impoundment of Czorsztyn Lake.

The phenomenon of seismicity induced or triggered by impoundments of water reservoirs is well known worldwide. Triggering is caused by a combined effect of two factors: (i) additional load of water accumulated in the reservoir, imposed on rock formations, which changes an initial stress field, and (ii) an increase of pore pressure in fault zones nearby the reservoir as a result of contraction of pores due to the changed stress field or by a fluid diffusion. In general, the second mechanism, which weakens the faults, is more important. The first factor acts immediately, results of the second can 
appear after some delay time. However, a necessary condition for earthquake triggering by water reservoirs is the existence of a tectonically loaded fault in the reservoir zone.

The best known example of the reservoir triggered seismicity is the case of Koyna reservoir in India, when seismicity started shortly after the impoundment in 1962 (Gupta 2002). Since the impoundment, more than 100 thousand earthquakes from magnitude $M \geq 0$ occurred. Ten earthquakes had magnitude $M \geq 5$.0. The strongest event took place on 10 December 1967 and had magnitude $M=6.3$. Koyna is not an isolated example. For instance, the Institute of Geophysics PAS in cooperation with the Institute of Geophysics, Vietnam Academy of Science and Technology, is monitoring earthquakes triggered by the impoundment of Song Tranh 2 dam reservoir in central Vietnam (Wiszniowski et al. 2014). Project details are available on the website www.is-epos.eu.

Impoundment of Czorsztyn Lake was completed in 1997, and the increase of the seismic activity has appeared 14 years later. Delayed seismic responses to reservoir impoundment were noticed on many instances around the world. 15 years after the impoundment of Aswan reservoir in Egypt an earthquake M5.4 was recorded in 1981 (Mekkawi et al. 2004). Around the reservoir Carno do Cajurain, Brasil, the delay was 18 years.

Czorsztyn Lake is shallow and the effect of the water load at depth is negligible. It is likely that the seismicity is a response to fault weakening due to diffusion effects. Regardless its cause, the earthquake triggering in this region would indicate existence of a fault or fault system being close to failure, which is quite surprising taking into account the rare tectonic seismicity occurrence in the area in both historical and instrumental periods.

Mutually close locations and similar focal mechanisms of earthquakes from Czorsztyn Lake region suggest that they are fracturing of the same segment of a strike slip fault. Seismic mechanism indicates that this fault strikes NS (Fig. 6.) This is not consistent with an alignment of epicenter locations (Fig. 4), which suggests NE-SW strike of the fault. The abovementioned detailed seismic profiling studies of the area, planned in the framework of IS-EPOS project, will help to clarify this problem.

Acknowledgments. This work was done in the framework of the project IS-EPOS "Digital Research Space of Induced Seismicity for EPOS Purposes" (POIG.02.03.00-14-090/13-00), funded by the National Centre for Research and Development in the Operational Program Innovative Economy in the years 2013-2015. 


\section{References}

Birkenmajer, K. (2003), Geological problems under study in the Pieniny Mountains, Pieniny Przyroda Człowiek 8, 33-40 (in Polish with English abstract).

Bajorek, L., and T. Zielińska (2010), Niedzica Hydro Powerplants jont stock company- reservoir creation and Company activity. In: R. Soja, S. Knutelski, J. Bodziarczyk (eds.), Pieniny - Zapora - Zmiany, Monografie Pienińskie, Vol. 2, 23-35 (in Polish with English abstract).

Gupta, H.K. (2002), A review of recent studies of triggered earthquakes by artificial water reservoirs with special emphasis on earthquakes in Koyna, India, Earth Sci. Rev. 58, 3-4, 279-310, DOI: 10.1016/S0012-8252(02)00063-6.

Guterch, B., H. Lewandowska-Marciniak, and J. Niewiadomski (2005), Earthquakes recorded in Poland along the Pieniny Klippen Belt, Western Carpathians, Acta Geophys. Pol. 53, 1, 27-45.

Kwiatek, G. (2011), FOCI - software for calculation of the seismic moment tensor and source parameters in mining environment, http://www.induced.pl/ projekty/foci.

Mekkawi, M., J.-R. Grasso, and P.-A. Schnegg (2004), A long-lasting relaxation of seismicity at Aswan reservoir, Egypt, 1982-2001, Bull. Seismol. Soc. Am. 94, 2, 479-492, DOI: 10.1785/0120030067.

Wiejacz, P. (1992), Calculation of seismic moment tensor for mine tremors from the Legnica-Głogów Copper Basin, Acta Geophys. Pol. 40, 2, 103-122.

Wiszniowski, J., N. Van Giang, B. Plesiewicz, G. Lizurek, D.Q. Van, L.Q. Khoi, and S. Lasocki (2014), Preliminary results of anthropogenic seismicity monitoring in the region of Song Tranh 2 reservoir, Central Vietnam, Acta Geophys. 63, 3, 843-862, DOI: 10.1515/acgeo-2015-0021.

Received 24 November 2014 Received in revised form 24 March 2015 Accepted 26 March 2015 